\title{
Pawet Szwajdler
}

Uniwersytet Kazimierza Wielkiego, Bydgoszcz

Okręgowa Izba Radców Prawnych w Toruniu

pawel.szwajdler@onet.pl

ORCID: https://orcid.org/0000-0003-1442-4229

\section{Notion of Market Manipulation in the Areas of Administrative Law and Criminal Law in the Legal Systems of Selected Member States of the European Union}

http://dx.doi.org/10.12775/SIT.2020.016

\section{Introduction}

Market manipulation is a very wide and multiperspective notion which is extremely troublesome to define. ${ }^{1}$ Such market abuse can

${ }^{1}$ M. Fox, L. Glosten, G. Rauterberg, Stock Market Manipulation and Its Regulation, "Yale Journal on Regulation" 2018, Vol. 35, p. 69; T. Putniṇš, Market Manipulation a Survey, "Journal of Economic Surveys" 2012, Vol. 26, No. 5, p. 952-953; I. Klepitskij, Market Manipulation in Russia and in Europe: the Criminal Law Dimension, "Russian Law Journal" 2016, Vol. IV, Issue 3, p. 126; B. Kozinn, The Great Copper Caper: Is Market Manipulation Really a Problem in the Wake of the Sumitomo Debacle, "Fordham Law Review" 2000, Vol. 69, p. 255; D. Fischel, D. Ross, Should the law prohibit "manipulation" in financial markets?, "Harvard Law Review" 1991, Vol. 105, No. 2, p. 506; M. Nelemans, Redefining Trade- Based Manipulation, "Valparaiso University Law Review" 2008, Vol. 42, No. 4, p. 1169; G. G. S. Fletcher, Legitimate Yet Manipulative: The Conundrum of Open-Market Manipulation, "Duke Law Journal" 2018, 
have implications not only in the area of penal law ${ }^{2}$ but also in the area of administrative law. ${ }^{3}$ It seems that criminal liability should be related only to the most radical examples of market manipulation. It is crucial to show boundaries between market manipulation, which should be penalised, and market manipulation, which should be only related to imposing administrative sanctions. It let precisely define features of the prohibited act which is criminal market manipulation.

This paper primarily includes the analysis of the legal regulations concerning market manipulation which are in force in most developed Member States of the European Union. Legal definitions related to market manipulation differ in European countries, although common source of elaborated regulations is secondary European legislation, namely MAD II ${ }^{4}$ and MAR. ${ }^{5}$ The reason of above - mentioned differences is the wide autonomy of Member States in the area of criminal law also concerning financial instrument trading.

\section{Definition of market manipulation}

It is probably impossible to strictly define legal term of market manipulation. ${ }^{6}$ It stems from the fact that legal definitions of market

Vol. 68, p. 481; D. Gerace, C. Chew, C. Whittaker, P. Mazzola, Stock Market Manipulation on the Hong Kong Stock Exchange, "AABFJ" 2014, Vol. 8, No. 4, Special Issue on Financial Planning \& Financial Instruments, p. 106 and 108.

2 P. Staikouras, Regulating Insider Trading and Market Manipulation in Greece: Normative Transplants and Conceptual Confusion, "Yearbook of International Financial and Economic Law" 2000-2001, Vol. 5, p. 472.

${ }^{3}$ Ibidem.

4 Directive 2014/57/EU of The European Parliament and of the Council of 16 April 2014 on criminal sanctions for market abuse (market abuse directive), L. $173 / 179$ of 12 June 2014.

${ }^{5}$ Regulation (EU) No 596/2014 of the European Parliament and of the Council of 16 April 2014 on market abuse (market abuse regulation) and repealing Directive 2003/6/EC of the European Parliament and of the Council and Commission Directives 2003/124/EC, 2003/125/EC and 2004/72/EC, L. 173/1 of 12 June 2014.

${ }^{6}$ D. Fischel, D. Ross, Should the law, p. 553; M. Nelemans, Redefining Trade-Based, p. 1169; M. Fox, L. Glosten, G. Rauterberg, Stock Market, p. 71. 
manipulation are in principle imperfect, too wide ${ }^{7}$ and imprecise ${ }^{8}$ because market manipulation is a very complex ${ }^{9}$ economic notion which is non- definable in legal language. ${ }^{10}$ Some scholars find out that it is difficult task to find differences between manipulative and legitimate conducts of traders. ${ }^{11}$ Hence, legal definitions of market manipulation are criticized in the whole world. ${ }^{12}$ Therefore, application of legal regulations prohibiting market manipulation is troublesome. ${ }^{13}$ In opinions of some lawyers, it is less problematic to analyse, if some conduct is manipulative in descriptive way, then create normative side of the notion of market manipulation. ${ }^{14}$ Therefore, manipulative nature of traders' conducts should be analysed by expert witnesses.

Some scholars suggest that market manipulation should be distinguished from legitimate activities like hedging, speculation ${ }^{15}$ or arbitrage.${ }^{16}$ It is crucial to be aware that some conducts, which are similar to market manipulation, can turn out to be legal. ${ }^{17}$ Therefore, legal definition of criminal market manipulation should not be wide.

It is also worth to state that understanding of market manipulation has changed over the years. The example of such change is the fact, that currently acceptable short selling was thought to be manipulative in the past. ${ }^{18}$

7 M. Nelemans, Redefining Trade-Based, p. 1169.

${ }_{8}$ M. Fox, L. Glosten, G. Rauterberg, Stock Market, p. 71.

${ }^{9}$ M. Nelemans, Redefining Trade-Based, p. 1171.

${ }^{10}$ B. Kozinn, The Great Copper, p. 248-249.

11 D. Fischel, D, Ross, Should the law, p. 522; T. Brennan, De-Mystifying Market Manipulation (Reviews), "Regulations" 2019, Vol. 42, Issue 3, p. 55;

D. Gerace, C. Chew, C. Whittaker, P. Mazzola, Stock Market, p. 106.

12 D. Fischel, D. Ross, Should the law, p. 506.

${ }_{13}$ M. Nelemans, Redefining Trade-Based, p. 1210.

14 Ibidem, p. 1177.

15 T. Brennan, De-Mystifying, p. 54-55.

${ }^{16}$ D. Gerace, C. Chew, C. Whittaker, P. Mazzola, Stock Market, p. 106.

17 D. Fischel, D. Ross, Should the law, p. 45; D. Gerace, C. Chew, C. Whittaker, P. Mazzola, Stock Market, p. 106.

18 D. Fischel, D. Ross, Should the law, p. 504. 
Despite the above- mentioned problems related to the notion of market manipulation, it is justified to try to define this term and to show differences between market manipulation in the areas of penal law and administrative law because it let strictly define features of penalised market manipulation.

To describe the notion of market manipulation, it is necessary to indicate that manipulator's aim is to make prices of securities not reflecting their value ${ }^{19}$ which is in common opinion achieved by fraud or misleading statements. ${ }^{20}$

Some scholars suppose that the most important feature of manipulation is direct link between manipulative transaction and the prices of securities. ${ }^{21}$ The influence on demand or supply is not so important because only affecting the price is a key to manipulation. ${ }^{22}$ It should be analysed if potentially manipulative behaviour puts price pressure. ${ }^{23}$ In the case of market manipulation such pressure should be illegitimate and artificial because each stock transaction puts some pressure on the prices of securities. ${ }^{24}$ Influence on price is artificial if the only aim of manipulative transaction is affecting the price. ${ }^{25}$

19 F. Londoño Martínez, Ilícito De Manipulación Bursátil: Fenómeno Y Lesividad. Aspectos De Política Sancionatoria, "Política Criminal" 2013, Vol. 8, No. 15, p. 102.

${ }^{20}$ Ibidem, p. 103; P. Staikouras, Regulating Insider, p. 480; I. Klepitskij, Market Manipulation, p. 120; S. Dolgopolov, Securities Fraud Embedded in the Market Structure Crisis: High-Frequency Traders as Primary Violators, "William and Mary Business Law Review” 2018, Vol. 9, p. 578.

${ }^{21}$ D. Fischel, D. Ross, Should the law, p. 513; M. Nelemans, Redefining Trade-Based, p. 1169 and 1179; T. Brennan, De-Mystifying, p. 54.

${ }^{22}$ D. Fischel, D. Ross, Should the law, p. 513; S. Dolgopolov, Securities Fraud, p. 594.

${ }^{23}$ M. Nelemans, Redefining Trade-Based, p. 1177; T. Putniṇš, Market Manipulation, p. 954-955.

${ }^{24}$ M. Nelemans, Redefining Trade-Based, p. 1177; T. Putnin̨š, Market Manipulation, p. 954-955, D. Fischel, D Ross, Should the law, p. 546.

${ }^{25}$ D. Fischel, D. Ross, Should the law, p. 508, B. Kozinn, The Great Copper, p. 258. 
Misleading nature of market manipulation is related to spreading false information concerning securities. ${ }^{26}$ Such information can be diffused verbally or by actual measures. ${ }^{27}$

It should be found out that definition of fraud can differ in various legal systems. Therefore, it is not easy task to discuss fraudulent nature of market manipulation in the aspect of comparative law. There are scholars who state that manipulation is "a particular type of fraud". ${ }^{28}$ Notwithstanding fraudulent nature of market manipulation is called into question because lots of manipulative transactions do not result in disadvantageous disposal of property. ${ }^{29}$ It is obvious that there are fraudulent kinds of market manipulation in each of legal systems but it can also exist non- fraudulent market manipulations. ${ }^{30}$

Fraudulent market manipulation is defined as trading by traders who have illegitimate intentions or purposes. ${ }^{31}$ Analysing intention of manipulator can turn out to be really difficult in practice. ${ }^{32}$ Therefore, it is suggested to create objective legal definitions of market manipulations which are not based on the notion of manipulator's intention. ${ }^{33}$ Definitions of market manipulation, which concern manipulator's intention, are known as subjective. ${ }^{34}$ In opinion

${ }^{26}$ B. Petcu, Fake News and Financial Markets: a 21st Century Twist on Market Manipulation, "American University Business Law Review" 2018, Vol. 7, p. 304; T. Lin, The New Market Manipulation, "Emory Law Journal" 2017, Vol. 66, p. 1284; H. Chitimira, Some Comments on the Enforcement Committee's Jurisdiction in the Adjudication and Settlement of Market Manipulation Cases: Pather and Another v Financial Services Board and Others [2014] 3 All SA 208 (GP), “Journal of African Law" 2018, Vol. 62, No. 3, p. 474.

${ }^{27}$ H. Chitimira, Some Comments, p. 474; B. Petcu, Fake News, p. 298-299, 307, 309 and note 192.

${ }^{28}$ P. Staikouras, Regulating Insider, p. 478.

29 D. Fischel, D. Ross, Should the law, p. 510.

30 Ibidem.

${ }^{31}$ Ibidem, p. 553; D. Gerace, C. Chew, C. Whittaker, P. Mazzola, Stock Market, p. 107-108.

32 D. Fischel, D. Ross, Should the law, p. 519.

33 Ibidem.

${ }^{34}$ M. Nelemans, Redefining Trade-Based, p. 1170; D. Fischel, D. Ross, Should the law, p. 519. 
of this paper's author, objective theory can be used for imposing administrative sanctions, whereas subjective theory seems to be appropriate for criminal liability.

There are opinions that anti-manipulations measures are valuable if they concern conducts which are not frauds. ${ }^{35}$ It is related to the fact that such regulations do not have superfluous nature. ${ }^{36}$ Notwithstanding such regulations should be enacted only in the area of administrative law because these legal rules do not refer to the notion of intention.

\section{Market Abuse Regulation}

Regulation No 596/2014 of 16 April 2014 on market abuse include the definition of market manipulation. ${ }^{37}$ It should be stipulated that this legal act was created so as to define stock manipulation in a very wide way which is suitable among others for imposing administrative sanctions. ${ }^{38}$ Whereas, issues related to criminal liability for market manipulation are regulated in MAD II. ${ }^{39}$

According to article 12 of MAR, market manipulation is abuse among others related to supply, demand or price. ${ }^{40}$ Furthermore,

35 I. Klepitskij, Market Manipulation, p. 123.

${ }^{36}$ Ibidem.

37 Art. 12 of Regulation (EU) No 596/2014 of the European Parliament and of the Council of 16 April 2014 on market abuse (market abuse regulation) and repealing Directive 2003/6/EC of the European Parliament and of the Council and Commission Directives 2003/124/EC, 2003/125/EC and 2004/72/EC, L. 173/1 of 12 June 2014.

${ }^{38}$ Point 71 of Regulation (EU) No 596/2014 of the European Parliament and of the Council of 16 April 2014 on market abuse (market abuse regulation) and repealing Directive 2003/6/EC of the European Parliament and of the Council and Commission Directives 2003/124/EC, 2003/125/EC and 2004/72/EC, L. 173/1 of 12 June 2014.

39 Directive 2014/57/EU of The European Parliament and of the Council of 16 April 2014 on criminal sanctions for market abuse (market abuse directive), L. 173/179 of 12 June 2014.

40 Art. 12 of Regulation (EU) No 596/2014 of the European Parliament and of the Council of 16 April 2014 on market abuse (market abuse regulation) and 
manipulation also affects the prices of securities in an abnormal or in an artificial way. ${ }^{41}$ Manipulation does not exist if potentially manipulative conduct is justified by accepted reasons or market practices. ${ }^{42}$

Furthermore, on the base of above- mentioned regulation, transactions and conducts should be recognised as manipulative if they affect or can affect the prices of financial instruments. ${ }^{43}$

In opinion of this paper's author, discussed regulation concerning market manipulation is too wide and too overall. Because of this fact, potentially manipulative conducts identified on the base of this definition are so numerous and doubtful that recognising each of these conducts as criminal offence can turn out to be contrary to the principle of legal certainty. Hence, it could be impossible to indicate ex ante and ex post, which conducts are manipulative.

\section{Market Abuse Directive II}

Market Abuse Directive of 16 April 2014 is European legal act which regulates among others principles of criminal liability for market manipulation in Member States of the European Union. According to article 5 of this Directive, Member States should penalise intentional market manipulations. ${ }^{44}$ Under this regulation, Member States can resign from penalising less harmful market manipulations, but they are not obliged to do it. ${ }^{45}$

According to this regulation, market manipulation is understood as placing orders, concluding transactions or other conducts which

repealing Directive 2003/6/EC of the European Parliament and of the Council and Commission Directives 2003/124/EC, 2003/125/EC and 2004/72/EC,

L. $173 / 1$ of 12 June 2014 .

${ }^{41}$ Ibidem.

42 Ibidem.

${ }^{43}$ Ibidem.

${ }^{44}$ Art. 5 of Directive 2014/57/EU of the European Parliament and of the Council of 16 April 2014 on criminal sanctions for market abuse (market abuse directive), L. 173/179 of 12 June 2014.

${ }^{45}$ Ibidem. 
are misleading in relation to price of, demand for or supply of financial instrument. ${ }^{46}$ Above- mentioned market manipulation can also concern spot commodity contracts related to financial instruments. ${ }^{47}$ It should be repeated that, in opinions of some scholars, manipulative conducts can be related only to prices of the financial instruments, whereas affecting demand or supply is not essential to commit manipulative market abuse. ${ }^{48}$

On the base of discussed regulation, market manipulation is also keeping prices of financial instruments at artificial or at abnormal level. ${ }^{49}$ Using the term of abnormality can be criticized because some scholars state that penalised market manipulation can be related only to the notion of artificiality, whereas abnormality is the notion which concerns untypical legitimate conducts of traders. ${ }^{50}$ Artificial affecting the price is defined as changing the price in a "wrong" way. ${ }^{51}$ All above- mentioned behaviours can be justified by market practice which are accepted. ${ }^{52}$

According to regulations of MAD II, manipulation is also a conduct which is related to deceptions, contrivances or fictious devices. ${ }^{53}$

Furthermore, discussed regulation states that manipulation can have influence on benchmark in result of various misstatements. ${ }^{54}$

It should be found out that definition of market manipulation, according to MAD II, is objective because it is not based on the notion of manipulator's intention. ${ }^{55}$

46 Ibidem.

47 Ibidem.

${ }^{48}$ D. Fischel, D. Ross, Should the law, p. 513.

${ }^{49}$ Art. 5 of Directive 2014/A57/EU of the European Parliament and of the Council of 16 April 2014 on criminal sanctions for market abuse (market abuse directive), L. 173/179 of 12 June 2014.

50 M. Nelemens, Redefining Trade-Based, p. 1173.

51 S. Dolgopolov, Securities Fraud, p. 590.

52 Art. 5 of Directive 2014/57/EU of the European Parliament and of the Council of 16 April 2014 on criminal sanctions for market abuse (market abuse directive), L. 173/179 of 12 June 2014.

${ }^{53}$ Ibidem.

54 Ibidem.

${ }^{55}$ H. Chitimira, Selected Aspects of the Regulation of Insider Trading and Market Manipulation in the European Union and South Africa, "African Journal 


\section{German regulations}

German regulations related to market manipulation are extremely casuistic. Therefore, explanation of them in detail is not in line with the aim of this article. Nevertheless, it is necessary to focus on interesting construction of them. Market manipulation is penalised on the base of par. 119 of Wertpapierhandelsgesetz. ${ }^{56}$ This regulation is based on par. 120 of Wertapapierhandelsgesetz, which states in detail, what kinds of conducts are administrative torts being market manipulation. ${ }^{57}$

According to par. 119 Wertpapierhandelsgesetz, person can be brought to criminal liability for a market manipulation if this person commits manipulation related to administrative sanctions and fulfils a few additional conditions. These additional conditions concern influence of the market manipulation on:

- prices of financial instruments or commodity contracts related to these financial instruments; ${ }^{58}$

- prices of commodities or currencies in Germany or abroad;59

- value of national or foreign benchmark. ${ }^{60}$

In opinions of German scholars, affecting above- mentioned prices and benchmarks is thought to stem from behaviour of manipulator if there is a cause and effect relationship between the conduct and the price of the financial instrument. ${ }^{61}$ In the case

of Legal Studies” 2016, Vol. 8, Issues 3-4, p. 203; P. Staikouras, Regulating Insider, p. 473.

56 Par. 119 of Wertpapierhandelsgesetz vom 9. September 1998 (BGBl. I S. 2708), https://www.gesetze-im-internet.de/wphg/ (access: 21.05.2020 r.).

${ }^{57}$ Par. 120 of Wertpapierhandelsgesetz vom 9. September 1998 (BGBl. I S. 2708), https://www.gesetze-im-internet.de/wphg/ (access: 21.05.2020 r.).

58 Par. 119 of Wertpapierhandelsgesetz vom 9. September 1998 (BGBl. I S. 2708), https://www.gesetze-im-internet.de/wphg/ (access: 21.05.2020 r.).

59 Ibidem.

60 Ibidem.

61 S. Birkner, Der Einwirkungserfolgbeider Marktmanipulationim Kontextnationalen und europäischen Rechts, http://telc.jura.uni-halle.de/sites/default/ /files/BeitraegeTWR/Heft\%20155.pdf (access: 21.05.2020 r.), p. 14. 
of lack of such influence, manipulator can be punished only administratively. ${ }^{62}$

Criminal liability for market manipulation in Germany is limited only to manipulative conducts which affect prices. ${ }^{63}$ It is compatible with American scholars' opinion, according to which manipulative conduct is directly linked with the price of financial instrument. ${ }^{64}$ It seems to be reasonable to penalise only conducts, which affect the price in a direct way, because it let explicitly define features of criminal market manipulation.

It should be found out that German regulation related to criminal market manipulation was created by reference to administrative market manipulation which should meet additional conditions concerning affecting prices or benchmarks. ${ }^{65}$

\section{French regulations}

There are separately regulations related to administrative and criminal market manipulation in France. According to art. 465-3-1 of Code monétaire et financier, it is prohibited under penalty of law to place orders, to conclude transactions, and to behave affecting in a fraudulent way supply of, demand for and price of financial instrument. ${ }^{66}$ Behaviours mentioned in last sentence are also punished if they can probably affect the price of financial instrument in an abnormal or in an artificial way. ${ }^{67}$

62 S. Birkner, Der Einwirkungserfolgbeider, p. 14.

${ }^{63}$ Par. 119 of Wertpapierhandelsgesetz vom 9. September 1998 (BGBl. I S. 2708), https://www.gesetze-im-internet.de/wphg/ (access: 21.05 .2020 r.).

${ }^{64}$ D. Fischel, D. Ross, Should the law, p. 513; M. Nelemans, Redefining Trade-Based, p. 1169 and 1179; T. Brennan, De-Mystifying, p. 54.

65 Par. 119 of Wertpapierhandelsgesetz vom 9. September 1998 (BGBl. I S. 2708), https://www.gesetze-im-internet.de/wphg/, (access: 21.05 .2020 r.).

${ }^{66}$ Art. 765-3-1 of Code monétaire et financier, Ordonnance $\mathrm{n}^{\circ} 2000-1223$ du 14 décembre 2000, https://www.legifrance.gouv.fr/affichCode.do?cidTexte =LEGITEXTO00006072026 (access: 21.05.2020).

${ }^{67}$ Ibidem. 
Art. 621-15 III bis p. 1 of Code monétaire et financier concerning administrative liability for market manipulation directly refers to MAR without defining the notion of market manipulation. ${ }^{68}$

In the opinions of French scholars, in the case of administrative and civil liability for market manipulation, the affection of the manipulator on the prices of securities can be fraudulent or misleading. ${ }^{69}$ Whereas, according to above- mentioned penal regulation, such influence must be fraudulent. ${ }^{70}$

It can be stated that penalised market manipulation in France is a particular type of fraud. Some scholars are in opinion that only some kinds of market manipulations are fraudulent. ${ }^{71}$ It means that only most serious market manipulations are penalised. Rest of market manipulations can be only related to administrative liability. Furthermore, committing fraud requires intention of manipulator. Therefore, French definition of criminal market manipulation has subjective nature.

In view of the above, some remarks should be made. Firstly, penal regulation concerning market manipulation should be directly regulated in national legal act. Whereas administrative definition of market manipulation can refer to European secondary law. Secondly, notion of market manipulation in the area of criminal law should be narrower than analogous notion in the area of administrative law. Thirdly, penalised market manipulation should be fraudulent, while administrative market manipulation can be misleading or fraudulent. ${ }^{72}$ Therefore, criminal liability for market

68 Art. 621-15 III bis p. 1 of Code monétaire et financier, Ordonnance $\mathrm{n}^{\circ}$ 2000-1223 du 14 décembre 2000, https://www.legifrance.gouv.fr/affichCode.do?cidTexte=LEGITEXT000006072026 (access: 21.05 .2020 r.).

69 J. M. Brigant, Infractions boursieres, https://www.cairn.info/revue-descience-criminelle-et-de-droit-penal-compare-2014-1-page-85.htm (access: 21.05.2020 r.), par. 10 .

70 Art. 765-3-1 of Code monétaire et financier, Ordonnance $\mathrm{n}^{\circ} 2000-1223$ du 14 décembre 2000, https://www.legifrance.gouv.fr/affichCode.do?cidTexte =LEGITEXT000006072026 (access: 21.05.2020 r.).

${ }^{71}$ D. Fischel, D. Ross, Should the law, p. 510; D. Gerace, C. Chew, C. Whittaker, P. Mazzola, Stock Market, p. 107.

72 J. M. Brigant, Infractions boursieres, par. 10; Art. 765-3-1 of Code monétaire et financier, Ordonnance $\mathrm{n}^{\circ}$ 2000-1223 du 14 décembre 2000, https:// 
manipulation can be brought only by person who affects the market with intent to commit a fraud. According to French regulation, market manipulation in the area of criminal law is a particular type of fraud. Hence, it should lead other investors to disadvantageous disposal of their property.

\section{Italian regulations}

In Italy criminal and administrative liabilities for market manipulation are regulated in art. 185 and art. 187-3 of Il testo unico delle disposizioni in materia di intermediazione finanziaria (TUF). ${ }^{73}$

According to art. 185 of TUF, criminal liability is brought by person who carries out artificial operations or affecting price of financial instrument in other artificial way. ${ }^{74}$ In view of this regulation, criminal liability can be brought only by person whose conducts are unreal and affect the price of the financial instrument.

Administrative liability (without regard for criminal liability) can be related only to conducts which are misleading in respect of price of, supply of and demand for financial instrument. ${ }^{75}$ Furthermore, according to art. 187-3 of TUF, administrative liability is brought by persons whose conducts let set prices at artificial or at abnormal level. ${ }^{76}$ Thus, notion of market manipulation in the area of administrative law in Italy is wider than analogous definition which exists in the area of criminal law.

www.legifrance.gouv.fr/affichCode.do?cidTexte=LEGITEXT000006072026 (access: 21.05.2020 r.).

${ }^{73}$ Il testo unico delle disposizioni in materia di intermediazione finanziaria, Decreto legislativo 24 febbraio 1998, n. 58, https://www.brocardi.it/testounico-intermediazione-finanziaria/ (access: 21.05.2020 r.).

74 Art. 185 of Il testo unico delle disposizioni in materia di intermediazione finanziaria, Decreto legislativo 24 febbraio 1998, n. 58, https://www.brocardi. it/testo-unico-intermediazione-finanziaria/ (access: 21.05.2020 r.).

${ }^{75}$ Art. $187-3$ of Il testo unico delle disposizioni in materia di intermediazione finanziaria, Decreto legislativo 24 febbraio 1998, n. 58, https://www.brocardi. it/testo-unico-intermediazione-finanziaria/ (access: 21.05.2020).

76 Ibidem. 
In view of the above, artificial influence on prices of financial instruments can be related both to criminal and administrative liability, whereas abnormal affecting on securities' prices can be sanctioned only by administrative law. ${ }^{77}$ The essential difference between administrative and criminal market manipulation concerns the notions of artificiality and abnormality. The notion of artificiality is thought to be more precise and narrower than the notion of the abnormality. ${ }^{78}$ Abnormality can be related to untypical influence of market operations on the prices of financial instruments, whereas artificial influence can be made only with intent to change the price of the financial instrument. ${ }^{79}$

\section{Spanish regulations}

There are separate administrative sanctions and penal punishments for market manipulation in Spain. ${ }^{80}$

According to art. 2.1 of Real Decreto 1333/2005, market manipulation in the area of administrative law is an abuse of a dominant position in financial market. ${ }^{81}$ Such abuse can be achieved by setting the price of financial instrument or by selling or buying financial instrument at the closing the market with intent to mislead other investors. ${ }^{82}$ Furthermore, practices related to spreading false information can be considered as administrative market manipulation..$^{83}$

77 Ibidem.

${ }^{78}$ M. Nelemens, Redefining Trade-Based, p. 1173.

79 Ibidem.

$80 \mathrm{~J}$. Castanion, Problemas de tipicidad en las conductas de manipulación de precios de los mercados de valores, "Nuevo Foro Penal" 2014, No. 82, p. 39.

${ }^{81}$ Real Decreto 1333/2005, de 11 de noviembre, por el que se desarrolla la Ley 24/1988, de 28 de julio, del Mercado de Valores, en materia de abuso de mercado, https://www.boe.es/buscar/act.php?id=BOE-A-2005-19251 (access: 21.05.2020).

82 Ibidem.

83 Ibidem. 
Spanish penal regulation concerning market manipulation is enacted in art. 284 of Spanish Penal Code. ${ }^{84}$ According to this regulation, market manipulation is punishable if it is committed by threats, violence or fraud. ${ }^{85}$ It should be stated that market manipulation is particular type of other offences.

In view of the above, Spanish definition of penalised market manipulation is subjective because committing fraud, committing act of violence or threatening require acting with intention.

\section{Boundaries between criminal liability and administrative liability for market manipulation}

Criminal and administrative liabilities are related to two possible (not mutually exclusive) methods of counteracting market manipulation. ${ }^{86}$ It is understood because two methods of sanctioning of market manipulation do not affect the principle of ne bis in idem. ${ }^{87}$

On the base of MAD II, it can be stated that criminal sanctions may be limited only to the heaviest market manipulations but this limitation is not obligatory. ${ }^{88}$ Definition of market manipulation regulated in MAD II is narrower than definition which is enacted in MAR.

According to German regulations discussed in this article, it is possible to find out that criminal liability for market manipulation requires to fulfil additional conditions in comparison with administrative liability.

On the base of French regulations and French legal doctrine, it can be stated that market manipulation in the area of criminal

${ }^{84}$ Art. 284 of Código Penal de España de 23 de noviembre 1995.

85 Ibidem.

${ }^{86}$ J. M. Brigant, Infractions boursieres, par. 117.

87 Ibidem.

${ }^{88}$ Art. 5 of Directive 2014/57/EU of the European Parliament and of the Council of 16 April 2014 on criminal sanctions for market abuse (market abuse directive), L. 173/179 of 12 June 2014. 
law must be fraudulent. ${ }^{89}$ Whereas market manipulation in the area of administrative law can be only misleading and must fulfil criteria enacted in MAR. ${ }^{90}$

In Italian judgements, it is expressed that criminal liability requires to fulfil additional conditions in comparison with these which are required for administrative liability purposes. ${ }^{91}$ Italian definition of criminal market manipulation is narrower than definition concerning administrative market manipulation. It should be repeated that criminal liability in Italy can be brought only by person whose conducts are artificial. Administrative liability can concern such behaviours which are real, but have some manipulative effects.

In Spain penalised manipulation is a particular type of other offences. Whereas administrative market manipulation is, in principle, similar to manipulation defined in MAR.

\section{Conclusions}

Although anti- market manipulation measures in the Member States of the European Union have their source in European secondary law, anti- market manipulation regulations are created on the base of theoretical conceptions which were discussed in the part of this article concerning definition of market manipulation.

Definitions of penalised market manipulation in France and in Spain are based on subjective theory of market manipulation. It means that manipulator must act with intention to commit market manipulation..$^{92}$

89 Art. 765-3-1 of Code monétaire et financier, Ordonnance $\mathrm{n}^{\circ}$ 2000-1223 du 14 décembre 2000, https://www.legifrance.gouv.fr/affichCode.do?cidTexte =LEGITEXT000006072026 (access: 21.05.2020 r.).

90 J. M. Brigant, Infractions boursieres, par. 10; art. 621-15 III bis p. 1 of Code monétaire et financier, Ordonnance $\mathrm{n}^{\circ}$ 2000-1223 du 14 décembre 2000, https://www.legifrance.gouv.fr/affichCode.do?cidTexte=LEGITEXT 000006072026 (access: 21.05.2020 r.).

91 J. M. Brigant, Infractions boursieres, par. 117.

92 M. Nelemans, Redefining Trade-Based, p. 1170; D. Fischel, D. Ross, Should the law, p. 519. 
German and Italian definitions of penalised market manipulation are objective. It means that they do not refer to the intentions of manipulator. ${ }^{93}$ Such definitions are thought to be too far- reaching because they can result in incriminating only suspicion of market manipulation. ${ }^{94}$

Furthermore, German penal regulation related to market manipulation is based on the theory, according to which the feature of harmful manipulation is direct link between manipulative transaction and the price of the financial instrument. ${ }^{95}$

In France, criminal market manipulation must be related to artificial affecting the price of the financial instrument, whereas such influence in the area of administrative law can be only abnormal. It stems from the theory, according to which artificiality is particularly harmful. ${ }^{96}$ Whereas abnormality can be even justified. ${ }^{97}$

In opinion of this work's author, two discussed kinds of market manipulation should be easy to distinguish. Therefore, it seems to be crucial to distinctly define additional features of penalised market manipulation.

Such definitions are in force in Germany, in Italy and in France. German and Italian penal regulations are based on the influence of manipulator on the prices of securities, whereas French regulation refers to the notion of artificiality of manipulator's conduct.

It should be stated that German and Italian countermeasures against market manipulation are defined in a clear way. Therefore, it seems to be quite easy to distinguish administrative and criminal market manipulation.

It is worth to highlight that German penal regulation is explicitly based on administrative regulation. It seems to be very correct and transparent legal solution. In opinion of this paper's author, such definition of market manipulation is exemplary.

93 D. Fischel, D. Ross, Should the law, p. 519.

${ }_{94}$ M. Nelemans, Redefining Trade-Based, p. 1210.

95 See. D. Fischel, D. Ross, Should the law, p. 513; M. Nelemans, Redefining Trade-Based, p. 1169 and 1179; T. Brennan, De-Mystifying, p. 54.

${ }_{96}$ M. Nelemens, Redefining Trade-Based, p. 1173.

${ }^{97}$ Ibidem. 
French regulation is based on unclear notion of artificiality. Hence, it can turn out to be problematic to distinguish two discussed kinds of market manipulation.

Furthermore, it should be noted that penalised market manipulation in Spanish legal system is a particular type of other offences. Therefore, discussed regulation is not necessary.

In view of the above- mentioned considerations, it should be stated that notion of market manipulation can be understood in two ways. First of them, which is wider, should exist in the area of administrative law. Second of them, which is narrower, should be applied for criminal law purposes. It seems to be compatible with the principle of proportionality. According to this principle, criminal liability should be brought only by persons whose conducts are particularly unacceptable.

\section{SUMMARY}

Notion of Market Manipulation

in the Areas of Administrative Law and Criminal Law in the Legal Systems of Selected Member States

of the European Union

The aim of the author of this paper is to show boundaries between penalised market manipulation and market manipulation which can be sanctioned only by administrative countermeasures. This task was achieved in result of analysing German, French, Italian and Spanish legal regulations concerning market manipulation. Above--mentioned analysis is based on theoretical issues which are discussed in the part of this work concerning definition of market manipulation. European regulations related to market manipulation are also elaborated in this article. Differences between penalised market manipulation and administrative market manipulation are creatively and synthetically discussed in the separate part of this work. Theoretical sources of differences between discussed regulations concerning administrative market manipulation and criminal market manipulation are elaborated in the summary.

Keywords: market manipulation; administrative liability; criminal liability 


\title{
STRESZCZENIE
}

\author{
Pojęcie manipulacji instrumentami finansowymi \\ w aspekcie karno- i administracyjnoprawnym \\ w porządkach jurydycznych wybranych \\ państw członkowskich Unii Europejskiej
}

Celem niniejszego opracowania jest wskazanie granic pomiędzy penalizowaną manipulacją instrumentami finansowymi a manipulacją, która może rodzić wyłącznie konsekwencje w postaci nałożenia sankcji administracyjnoprawnych. Określone powyżej zadanie zostało zrealizowane na podstawie analizy regulacji normatywnych, które obowiązują w Niemczech, we Francji, we Włoszech oraz w Hiszpanii. Badając poszczególne przepisy prawne obowiązujące $\mathrm{w}$ wymienionych państwach, posiłkowano się zagadnieniami teoretycznymi, które przedstawione zostały we fragmencie niniejszego artykułu dotyczącym definicji manipulacji instrumentami finansowymi. W opracowaniu tym omówione zostały również regulacje wtórnego prawa unijnego stanowiące źródło, na podstawie którego stworzono analizowane przepisy. W sposób syntetyczny różnice pomiędzy dwoma omawianymi typami manipulacji zostały przedstawione i twórczo przeanalizowane w odrębnym fragmencie pracy. Artykuł zakończony został podsumowaniem, w którym wskazano teoretycznoprawne źródła zastosowanych w przedmiotowych regulacjach prawnych kryteriów rozróżniania obu rodzajów manipulacji instrumentami finansowymi.

Słowa kluczowe: manipulacja instrumentami finansowymi; odpowiedzialność administracyjnoprawna; odpowiedzialność karnoprawna

\section{BIBLIOGRAPHY}

Birkner S., Der Einwirkungserfolgbeider Marktmanipulationim Kontextnationalen und europäischen Rechts, http://telc.jura.uni-halle.de/sites/ /default/files/BeitraegeTWR/Heft\%20155.pdf_(access: 21.05.2020 r.). Brennan T., De-Mystifying Market Manipulation (Reviews), "Regulations" 2019, Vol. 42, Issue 3.

Brigant J. M., Infractions boursieres, https://www.cairn.info/revue-descience-criminelle-et-de-droit-penal-compare-2014-1-page-85.htm (access: 21.05.2020 r.). 
Castanion J., Problemas de tipicidad en las conductas de manipulación de precios de los mercados de valores, "Nuevo Foro Penal" 2014, No. 82. Chitimira H., Selected Aspects of the Regulation of Insider Trading and Market Manipulation in the European Union and South Africa, "African Journal of Legal Studies" 2016, Vol. 8, Issues 3-4.

Chitimira H., Some Comments on the Enforcement Committee's Jurisdiction in the Adjudication and Settlement of Market Manipulation Cases: Pather and Another v Financial Services Board and Others [2014] 3 All SA 208 (GP), “Journal of African Law” 2018, Vol. 62, No. 3.

Dolgopolov S., Securities Fraud Embedded in the Market Structure Crisis: High-Frequency Traders as Primary Violators, "William and Mary Business Law Review" 2018, Vol. 9.

Fischel D., Ross D., Should the law prohibit "manipulation" in financial markets?, "Harvard Law Review" 1991, Vol. 105, No. 2.

Fletcher G. G. S., Legitimate Yet Manipulative: The Conundrum of OpenMarket Manipulation, “Duke Law Journal” 2018, Vol. 68.

Fox M., Glosten L., Rauterberg G., Stock Market Manipulation and Its Regulation, "Yale Journal on Regulation" 2018, Vol. 35.

Gerace D., Chew C., Whittaker C., Mazzola P., Stock Market Manipulation on the Hong Kong Stock Exchange, “AABFJ" 2014, Vol. 8, No. 4, Special Issue on Financial Planning \& Financial Instruments.

Klepitskij I., Market Manipulation in Russia and in Europe: the Criminal Law Dimension, "Russian Law Journal” 2016, Vol. IV, Issue 3.

Kozinn B., The Great Copper Caper: Is Market Manipulation Really a Problem in the Wake of the Sumitomo Debacle, "Fordham Law Review" 2000, Vol. 69.

Lin T., The New Market Manipulation, “Emory Law Journal” 2017, Vol. 66.

Londoño Martínez F., Ilícito De Manipulación Bursátil: Fenómeno Y Lesividad. Aspectos De Política Sancionatoria, "Política Criminal" 2013, Vol. 8. No. 15.

Nelemans M., Redefining Trade- Based Manipulation, "Valparaiso University Law Review” 2008, Vol. 42, No. 4.

Petcu B., Fake News and Financial Markets: a 21st Century Twist on Market Manipulation, “American University Business Law Review” 2018, Vol. 7.

Putniṇš T., Market Manipulation a Survey, "Journal of Economic Surveys" 2012, Vol. 26, No. 5.

Staikouras P., Regulating Insider Trading and Market Manipulation in Greece: Normative Transplants and Conceptual Confusion, "Yearbook of International Financial and Economic Law" 2000-2001, Vol. 5. 
